\title{
Problems and Challenges Facing Today's Construction Sector in Albania
}

\author{
Ariet Malaj \\ Akademia Profesionale e Biznesit; amalaj@uab.edu.al
}

Ingrid Shuli

Fakulteti Ekonomise, UT; ingridshuli@gmail.com

\section{Doi:10.5901/ajis.2015.v4n3s1p572}

\section{Abstract}

In the early 90's one of the most powerful sectors of the economy has been the construction, which has seen considerable growth in value. Today this market is growing at a slower rate than in the first years of transition. Some of the causes of this progress are the world economic crisis, limited sources of financing, the informal economy, etc. Through the study of foreign literature and the experiences of the country in this field we try to identify the problems encountered today in the construction sector and its prospects. This paper will present the construction sector as a whole, from its impact on GDP, the funding problems, and the constant requests from the sector for improvements in the tax system. Through a survey conducted in major construction firms operating in Albania we realize that construction firms should pay more and more attention to the improvement of management and they must start to work with studies and projects prepared before. Regarding the methodology used, most represented by: Secondary data carefully analyzed seriously. The methodology used is based on analysis of legislation in this area as well as studies conducted in developed countries. Are used in various international reports, conference papers, statistical database, online publications, and various online sites to meet the objectives of the study in question. Primary data that are acquired through survey of construction companies and meetings with representatives of tax authorities. The difficulties were mainly related to the skepticism on the procurement of information. The construction sector and construction activities are considered major sources of economic growth. It can be considered as a mechanism for generating employment by providing employment opportunities to a large number of unskilled employees, semi-skilled and skilled.

Keywords: construction sector, financial crisis, economical crisis, gross domestic product.

\section{Review of Literature}

For the construction sector, has an extensive literature and world manifold. Are focused on developments that have occurred in the field of management and accounting contributions and accounting standards in this development. The International Standards are specifically referred to 11 on "Construction Contracts", which stops specifically in the recognition of revenue related to this sector, the important point for determining the exact result on the basis of which the obligations are calculated on the state budget. Local literature to which they are mostly related to the publications of the Association Constructors, which takes the analysis in detail all the problems, constraints and administrative obstacles facing the sector nowadays.

\section{The Role of Construction in the Albanian Economy}

The process of transition from a centrally planned economy to a free market economy is not only associated with the transformation mechanisms and infrastructure for the functioning of markets, but above all with the need of development and creation of instruments and the new legal spaces, institutional, economic and social policies aimed at increasing the efficiency and use of public and private sources. Ratings and economic developments confirm that the Albanian economy over the last decade is characterized by a high economic growth and sustainable.

According to Albanian Institute of Statistics (INSTAT) and to the bank of Albania, during the transition period one of the most powerful has been the construction sector, which for years had risen considerably. Highest percentage of contribution are made by the years 2000 and 2004 respectively to $2.6 \%, 2.5 \%, 2.1 \%$ and $2.6 \%$ versus Gross Domestic Product (GDP). In this sector is estimated to have over 50 thousand employees. The construction sector accounts an 
important contribution in our Gross Domestic Product (GDP). In terms of percentage on GDP from the construction sector see the table below. for about 10 percent of Gross Domestic Product (GDP).

Table 1: The Structure of construction sector in percentage on GDP

\begin{tabular}{|l|c|c|c|c|c|c|c|c|c|}
\hline Years & $\mathbf{2 0 0 6}$ & $\mathbf{2 0 0 7}$ & $\mathbf{2 0 0 8}$ & $\mathbf{2 0 0 9}$ & $\mathbf{2 0 1 0}$ & $\mathbf{2 0 1 1}$ & $\mathbf{2 0 1 2}$ & $\mathbf{2 0 1 3}$ & $\mathbf{2 0 1 4}$ \\
\hline Construction sector & $12.90 \%$ & $13.40 \%$ & $9.40 \%$ & $8.50 \%$ & $9.40 \%$ & $8.80 \%$ & $7.70 \%$ & $10.50 \%$ & $12 \%$ \\
\hline
\end{tabular}

Contributes to the state budget every year in the form of fees and taxes, as follows.

The construction sector is the largest contributor to income tax in the country. In terms of fiscal revenue in the form of VAT from the construction sector in relation to other sectors we have this statement (in bln Albanian Lek - ALL):

Table 1: VAT of construction sector in years

\begin{tabular}{|l|c|c|c|c|c|c|c|c|c|c|}
\hline YEARS & $\mathbf{2 0 0 6}$ & $\mathbf{2 0 0 7}$ & $\mathbf{2 0 0 8}$ & $\mathbf{2 0 0 9}$ & $\mathbf{2 0 1 0}$ & $\mathbf{2 0 1 1}$ & $\mathbf{2 0 1 2}$ & $\mathbf{2 0 1 3}$ & $\mathbf{2 0 1 4}$ \\
\hline REVENUES FROM TAXES & \multicolumn{90}{|c|}{$\begin{array}{l}\mid 010 \\
\text { AND CUSTOMS }\end{array}$} & 123101 & 176808 & 205292 & 208870 & 223019 & 235509 & 232591 & 224105 & 260517 \\
\hline VAT & 58161 & 87771 & 107094 & 110062 & 113998 & 114000 & 113970 & 107570 & 125048 \\
\hline OTHER SECTORS & 43039 & 64951 & 80320 & 81446 & 85498 & 84610 & 84340 & 80678 & 93786 \\
\hline CONSTRUCTION SECTOR & 15122 & 22820 & 26774 & 28616 & 28500 & 29390 & 29630 & 26892 & 31262 \\
\hline
\end{tabular}

\section{Problems and Challenges of the Construction Sector: Informal Economy}

Situation of very prolonged transition that is going Albania today, is accompanied by a series of social and economic factors have created significant disproportion, social, economic, cultural as well, creating a suitable ground to avoid in order to open as statistical records and fiscal obligations. One of the sectors where you see that is not present on the implementation of legislation is the construction sector in particular given the whole production of construction materials.

Activities to be undertaken by the informal sector often performed in conjunction with one another, creating new forms of relationships between production, thus the construction and consumer companies, including construction companies and other consumers. In reality Albanian practice, faced with the obligation activities, unregistered, the immeasurable, which often rely on models of cooperation, mutual assistance, which are invisible to the authorities. Among the concealment of an activity may include: - Development of activity in terms of tax evasion (VAT, taxes, etc.), Shunning social contributions by not respecting the rules on working time, minimum wage, etc., - Lack of permits, licenses and other authorizations necessary administrative activities to develop.

The construction sector plays an important role in the growth of income per capita, as is engaged in a significant proportion of the active work force.

Although this sector has a large number of employees, compared with other sectors of the economy, the construction sector is ranked first with regard to illegal employment (as a form of appearance of informality). The existence of a high number of small enterprises in construction, made it difficult to control the labor market given the fact that trade union organization in this sector is in relatively poor condition. Responsibility for the very large size of the black labor in the construction sector is common because the state does not provide the appropriate level of law enforcement. Employers have a big responsibility too because they do not do not declare the necessary data for the construction sector.

Employee despite these difficulties should increase requirements to organize a union. They are not functioning properly union organization in this sector, and this makes difficult the control of the labor market. It is understood that the consequences of black market labor are heavy as in the economic, fiscal, and social, such as: -carrying deficit in the state budget; -decrease in income for Social Security accounts; -tax evasion related to income tax; -creating a vulnerable social stratum.

The economic consequences of financial crisis - Serious international economic crisis and its financial consequences are increasingly reflected the economy of our country. As mentioned above the construction sector has had and has a considerable weight in the budget, but this sector is currently suffering a lack of liquidity and funding, first because of the collapse of the banking credit to a general economy and construction sector in particular, and secondly, due to the fall of remittances from Albanians living abroad. The latter was known as an important source of financing for Albanian construction market. Since 2008, there is a significant reduction of throughput in the construction of housing. A 
strong reason for this decrease is the domestic market supersaturate constructions. Thus, if we take as an example in 2008, had very low turnover and the 2500 annual company registered at national level, about 600 have not worked. In the same period, has significantly increased the number of apartments, or unsold commercial environments. This reduction of the annual turnover is most noticeable in companies principally engaged in construction of apartments, while companies that are involved in public works (funded with state tenders) have increased the volume of their turnover.

What is actually observed decline in revenue, and laps too low compared to others, the companies active in the establishment of residential buildings. Indeed, the decline in construction sector this year was launched following the collapse of the last three years. The construction sector by 2014 sales reached a level of about $20 \%$ lower than in 2013 , while the decline was reflected in the amount of constructed surface and volume of work performed.

According to INSTAT building materials prices have increased by about $22 \%$ and low sales have hindered the recovery of funds. Construction prices during 2014 have increased less than they have grown from year to year. This is another sign that this sector is in trouble. According to the Bank of Albania fall in construction can provide rapid effect in the decline of economic growth as this sector is the most important contributor to the economy or sector with the largest contribution. Building collapse in such a percentage is very important to make the most critical level of expected growth. The state sector in 2014 has managed to carry a volume of works and spend an amount of money in building greater than 2013, while the decrease is found in private business. The fact that the decline in construction related mostly to private business declined indicates that some other indicators, such as purchasing power, cost of production, the climate has deteriorated to obtain a building permit, etc.

Bank of Albania in its reports to the public has often expressed concern about developments in the construction sector and states that fall in this sector can bring the entire economy as weakening the banking system is connected more with the construction sector, and majority of loans for the building is oriented. This concern of the Bank of Albania enables us to conclude that the decline in growth rates of the construction sector can lead to increased number and value of bad loans.

\section{Financing Options}

For many years, construction activity is funded in a slightly strange and interesting. Once a construction company received a permit to build an object (which is often such a thing does not happen), just before it needed to start construction. Very soon started bookings for apartments and business facilities, a process which continued until the full completion of the facility. The firm offered a discount for flats and shops sold. In financial terms this method of financing has two positive aspects: First, it provides the liquidity needed to continue further activity (to complete the facilities started). Second, given that for a period of time the firm had received advance money for the facility it is building, this means that it has secured the implementation of income.

If the price will fall flat, income for a construction firm will not fluctuate, because it has signed long term contracts and have received money in advance. Exposed to this risk would be buyers who at the time of signing the contract (purchase in advance), have ownership and title over these apartments. In contrast to the apartment price growth brings benefits to the buyer (the same as income from stock price growth) and revenues of retailers are still constant.

Internal migration and factors related to the elasticity of demand for apartments did the price of the latter to grow rapidly. Being a good profit this sector is not left outside attention of investors. As a result of increased competition this led to a construction firm, which had been an important segment of the market intended for keeping and why not to extend it further. Meanwhile, in recent years the market is growing at a slower pace than in the first years of transition. Demand for residential buildings has been reduced. The construction sector is showing signs of decline, in circumstances where: the market is over saturated, banks reduce lending, is the Albanian Lek depreciated and is strengthening euro, there is a high competition in this sector and the latter is characterized by price fixing the apartments. This is due to high profits accumulated by these investors, profits which are not in proportion with the risks to which they have undertaken in this business.

Despite the problems mentioned above, the construction sector has faced so far this sector has remained steadfast in fixing the selling prices, retail prices remain high, even though demand for apartments has fallen.

In these conditions, questions naturally arise: Where will the funds available to finance construction projects? What will be the future of construction firms? 


\section{The Survey Results}

According to Albanian Institute of Statistics (INSTAT) 2014 employees in construction firms occupy 16.1\% of total employees. Fluctuations of these entities have consequences at the macroeconomic level.

Purpose of the survey: Presentation of the current situation of the construction companies, the problems they encountered and their projections on the business climate.

\section{Research Methodology}

To conduct the survey was undertaken the following steps:

1. Determination of data to be collected during the survey. We asked to the construction companies about the time of operation in the Albanian market, about the cost of raw materials, and workshop materials, about the problems and concerns of the financing of projects, about the participation or not in the state procurement and finally about the use of statistical methods.

2. Design of the survey. To realize the survey we used question closed primarily with skirt. To prevent the subjectivity of the respondents to the question we used the open edge, to prevent also the concentration effect of responses. We also grouped the questions under the similar aspects.

3. Sampling. The population in this survey consists of all businesses in the construction field. Number of construction firms is 3.292 (INSTAT, 2014). There are two types of sampling:

1.Non-probability sampling. These types are divided: a)Eligibility; b)The intentional. Following the probability sampling, every element of the population has a known prior probability.

The size of the sample was 117 surveys completed.

\section{Summary Results}

From the answer about the age of firms we saw that $73.46 \%$ of firms surveyed have been operating in the range of $5-10$ years. The construction sector is seen as a sector in decline and unable to generate jobs. This fact is inconsistent with the survey conducted by INSTAT in 2014, where the result that employment in this sector increased by $1.0 \%$.

The construction companies also are unanimous in admitting that they have to delays in payment and delay the liquidation of purchase invoices. Sources of funding are internal and only a percentage of $26.56 \%$ are from bank loans.

Problems the construction companies are facing by the questionnaire analysis are linked with:

low borrowing from banks as a result of: collateral, high interest rates and bureaucracy; with Fiscal Legislation in the construction sector which is unclear and the extent of information is insufficient; with exaggerated requirements to obtain a building permit.

An interesting point results from the answers about state funds procurement. So about $76.5 \%$ of construction companies participate in public procurement. For all construction companies the main problem is the delay of the payment for the work completed.

Most of them uses or has used planning and evaluation methods to determine project costs.

\section{Conclusions}

The construction sector and construction activities are considered major sources of economic growth. It can be considered as a mechanism for employment generated offering employment opportunities to a large number of unskilled employees, semi-skilled and skilled. Construction planning is a fundamental and challenging activity in the management and implementation of construction projects. This process includes the selection of technology, definition of work, assessment of resources required and duration of specific tasks, and identification of interactions that connect some activities. A good construction plan is the basis for developing the budget and work planning. Prepare the building plan is a critical task in managing the construction. The problem of financing the projects is a key element in launching them or not. Prior owners raised various solution alternatives. Depending on the type of facility to build, technical terms, difficulties in analyzing alternative financing plans to select one that is more optimal value, without sacrificing quality of work and objectives of other builders.

Use of accounting standards in construction also seen as likely to report good quality financial situation. Submission to rules that impose standards will do avoid the phenomena that were mentioned during the paper on the 
attempt to tax evasion by construction firms. Reporting quality and reliability associated with banks and other financial specialists of the construction sector to provide necessary funds for the activity.

After evaluation of the cost monitoring and control of its construction makes the firm to react quickly to the differences that arise between performance budgeting and spending. The project manager construction facility must analyze the causes of these deviations and then make appropriate corrections in planning.

\section{References}

Ahuja, H.N. and W.J. Campbell, "Evaluation: From the concept to the fulfilment", Prentice-Hall, Englewood Cliffs, NJ,1987.

Bank of Albania, www.financa.gov.al.files

Chris Hendrickson, "Project Management for Construction", Prentice Hall, 1998

International Accounting Standards Commitee 1993). International Accounting Standard 11 "Construction Contracts".

INSTAT, Center for Research and Development, Tirana (2009), A study about the difficulties and obstacles albanian construction companies are facing.

Steven J. Peterson. "Construction Accounting And Financial Management", Prentice-Hall,New Jersey, 2009

"The constructor", Association's Constructor's Review, 2009 - 2014. 